\title{
Bread in the Desert: The Politics and Practicalities of Food in Early Egyptian Monasticism
}

\author{
Benjamin Hansen \\ Department of History, University of Minnesota, Twin Cities, Minneapolis, Minnesota, USA \\ Corresponding author. Email: hanse848@umn.edu
}

\begin{abstract}
The Apophthegmata Patrum (Sayings of the Desert Fathers) offer a compelling literary perspective on the daily lives of early Egyptian monastics. The routine necessities of food and drink played a distinct part in the physical and spiritual survival of these novel monastic communities. When, what, and how much a monk ate could cause celebration or scandal. Every meal was likewise a test. This study has two purposes. First, it situates the Sayings's many references to bread, salt, oil, and fruit within the dietary possibilities of late antique Egypt. Second, and more broadly, this study highlights the place of eating (or not eating) as it relates to particular monastic notions of spiritual wellbeing. Meals were always an arena for acts of heroic asceticism, but they also served as highly charged communal confrontations, a dizzying back and forth of hospitality received or rejected, of honor and shame played out in alimentary paradoxes. In this, the Sayings bear witness to the spiritual politics of eating within Egyptian monastic culture and provide insight into the formation of late antique religious identities, betraying fundamental tensions inherent in other forms of Christian literature.
\end{abstract}

Keywords: Food and Eating in Early Christianity; Egyptian Monasticism; Desert Fathers; Apophthegmata

\section{Introduction: The Apophthegmata Patrum}

The Sayings of the Desert Fathers, known more formally as the Apophthegmata Patrum, stand alongside texts such as the Life of Antony as the oldest layer of monastic literature in the Christian tradition. It has been customary to imagine that the monks of fourthcentury Egypt preserved and passed on these "sayings"-in reality, a various mix of spiritual teachings, parables, short stories, and even folktales. This was a complicated process of recitation, reformulation, attribution, and reattribution (much of this transmission history remains frustratingly opaque). ${ }^{1}$ Though many of these Sayings were

A version of this paper was first presented at the Premodern Food Cultures Conference at the University of Minnesota (October 2019). I owe thanks to those who offered comments there and who encouraged me to continue working on the topic. Additional thanks are owed to the anonymous reviewers who offered essential feedback and criticism in the revisions of this paper.

${ }^{1}$ For an introduction to the history and content of Egyptian monastic literature in English, see William Harmless, SJ, Desert Christians: An Introduction to the Literature of Early Monasticism (New York: Oxford

(c) The Author(s), 2021. Published by Cambridge University Press. This is an Open Access article, distributed under the terms of the Creative Commons Attribution licence (https://creativecommons.org/licenses/by/4.0/), which permits unrestricted re-use, distribution, and reproduction in any medium, provided the original work is properly cited. 
likely Coptic in origin, from the latter half of the fifth century, Christian communities in Palestine began to translate these collections into Greek. ${ }^{2}$ From Palestine, the Sayings became, like so much early monastic literature, a sort of international bestseller.

The translations multiplied: various ancient and medieval editions survive in Syriac, Coptic, Armenian, Georgian, Arabic, Ethiopic, and Old Slavonic. ${ }^{3}$ Saint Benedict of Nursia, for example, knew the Verba Seniorum-a fifth-century Latin rendition of these Sayings - and through him these texts helped to inform the monasticism of the Middle Ages in the West. ${ }^{4}$ Yet by far the most extensive collections are those extant in Greek. These include the Alphabetical Collection (attributed to individual ascetics by name), the Anonymous Collection, and the Systematic Collection (arranged by spiritual "topic," though with many attributions)..$^{5}$ Palestine's monks compiled the Alphabetical Collection first and then produced the Anonymous and Systematic Collections "within a generation or so" (in the recent judgement of John Wortley). ${ }^{6}$ As it stands, the Systematic Collection includes both Anonymous Sayings and the Alphabetical Sayings (though at times in augmented form), as well as material not found in either. ${ }^{7}$

University Press, 2004). Benedicta Ward offers a similarly lucid introduction to the history of these Sayings in her edition: The Sayings of the Desert Fathers: The Alphabetical Collection, trans. Benedicta Ward, 2nd ed. (Kalamazoo, Mich.: Cistercian Publications, 1984), xxvii-xxx (hereafter Ward, Sayings). A more recent and extensive treatment of the Sayings can now be found in John Wortley, An Introduction to the Desert Fathers (Cambridge: Cambridge University Press, 2019). Pioneering work on the textual history of these collections is found in Wilhem Bousset, Studien zur Geschichte des ältesten Mönchtums (Tübingen: Mohr,1923). Samuel Rubenson offers a recent summary of the twentieth-century historiography related to these Sayings in "The Formation and Reformations of the Sayings of the Desert Fathers," in Early Monasticism and Classical Paideia, ed. Samuel Rubenson (Leuven: Peeters, 2013), 5-22.

${ }^{2}$ In addition to Bousset's work, see Jean-Claude Guy, "Note sur l'évolution du genre apophthegmatique," Revue d'ascetique et mystique 32 (1956): 63-68; Samuel Rubenson, St. Anthony: Monasticism and the Making of a Saint (Minneapolis: Fortress, 1995), 145-162; and Martin Hinterberger, "Probleme der Texterstellung der Apophthegmata Patrum," Jahrbuch der Österreichischen Byzantinistik 46 (1996): 25-43.

${ }^{3}$ See relevant information in Harmless, Desert Christians, 183-190, esp. 248-251.

${ }^{4}$ Translated first into Latin by Pelagius and John the Deacon with a text reproduced in J. P. Migne, Patrologiae cursus completus: Series Latina, 221 vols. (Paris: Migne, 1844-1864), 73:855-1022.

${ }^{5}$ The Greek of the Alphabetical Collection can be found in J. P. Migne, Patrologia cursus completus: Series Graeca, 161 vols. (Paris: Migne, 1857-1866) (hereafter PG), 65:71-440; translated into English in Ward, Sayings; the Greek text of the Systematic Sayings is found (with a French translation) in Claude Guy's three-volume, Les Apophtegmes des Pères: collection systématique, Sources chrétiennes (hereafter SC) 387, 474, 498 (Paris: Éditions du Cerf, 1993, 2003, 2005, respectively); and an English translation of Guy's text is found in John Wortley, trans., The Book of the Elders: Sayings of the Desert Fathers (Collegeville, Minn.: Liturgical Press, 2012). Wortley also offers the Greek text and a translation of the Anonymous Collection in John Wortley, trans., The Anonymous Sayings of the Desert Fathers (Cambridge: Cambridge University Press, 2013). See Harmless, Desert Christians, 183-184, for further bibliographic information.

${ }^{6}$ Wortley, The Book of the Elders, vii.

${ }^{7}$ As it stands, there are about 1,000 sayings in the Alphabetical Collection, 1,200 in the Systematic, and 800 in the Anonymous. I have drawn most of my examples in this paper from the Alphabetical Collection inasmuch as they represent the oldest surviving collection. The attribution of a name, moreover, gives the Alphabetical Collection a certain narrative drama and heightens the contradictions when a single figure gives conflicting advice. Sayings found in both the Systematic and Alphabetical Collections, as well as those found only in the former, will be noted as such. Hereafter, the collections will be abbreviated as follows for citations: APalp for Alphabetical; APanon for Anonymous; and APsys for Systematic. 
The Sayings are almost endlessly interesting. Here, so Peter Brown wrote cheerfully, "the peasantry of Egypt spoke for the first time to the civilized world." ${ }^{8}$ The earthiness or "rusticity" of the content and presentation has evoked similar sentiments in a variety of scholars. Only more recently have some begun to question whether the Apophthegmata really do provide such immediate access to ancient Egyptian candor. ${ }^{9}$ As Claudia Rapp notes, a more direct access to the lived experience of late antique monasticism is found in other, more piecemeal sources: papyri, letters, and ostraca. ${ }^{10}$ What the Apophthegmata provide are caricatures, portraits whose relation to "the truth" is one of augmented, diminished, or rearranged reality. ${ }^{11}$ James Goehring has suggested we approach these texts as "imagined landscapes," mythic portrayals of ideal praxis. ${ }^{12}$ Samuel Rubenson, for his part, has argued that the Sayings tell us very much about the Palestinian monasticism of the fifth and sixth centuries and very little of Egyptian monasticism in the fourth. For Rubenson, the Sayings are a literary tradition with slight interest in our sense of history. ${ }^{13}$

Yet such portraits or "imagined landscapes" had an immeasurable and almost immediate influence on the literary output of late antique Christianity. Indeed, the recent emphasis on the literary and ideological aims of these collections serves to heighten the tensions within the Sayings themselves. In fact, the paradoxes and contradictions found within the Sayings stand out all the more if we understand them as the carefully constructed publicity of an idealized past. Moreover, the fact of the importance of Palestinian monasticism for the formation of this "Egyptian" corpus does not as a matter of course denote the obscuring of an earlier tradition by one that came later. Rather, we might suggest that this fact only serves to highlight the intimate bond between early Egyptian and early Palestinian monasticism, a bond of continuity incarnate in the endless stream of pilgrims, ascetics, and authors who moved through the porous border zone of Sinai. ${ }^{14}$ Contemporary texts such as Palladius's Lausiac History (fifth century CE) and later texts such as John Moschus's Spiritual Meadow (seventh century CE)

\footnotetext{
${ }^{8}$ Peter Brown, The World of Late Antiquity: AD 150-750 (New York: W. W. Norton, 1971), 100.

${ }^{9}$ In comparing the Apophthegmata to other collections of "gnomic sayings" in Greco-Roman philosophical training, Lillian I. Larsen implies that many scholars have begged the question as to whether there is an actual "authentic moment to be found" at the origin of these collections. Her conclusion that, whatever else the Sayings are, they represent an argument about "normative praxis" in budding monastic communities is certainly true and apropos of my argument. Lillian I. Larsen, "The Apophthegmata Patrum: Rustic Rumination or Rhetorical Recitation?” Patristica Nordica Anuuaria 23 (2008): 21-31, at 22 and 30.

${ }^{10}$ Claudia Rapp, "The Origins of Hagiography and the Literature of Early Monasticism: between Invention and Tradition," in Unclassical Traditions, vol. 1, Alternatives to the Classical Past in Late Antiquity, ed. C. Kelly, R. Flower, and M. S. Williams (Cambridge: Cambridge University Press, 2010), $119-130$, at $122-123$.

${ }^{11}$ See discussion of hagiography as caricature in Patricia Cox, Biography in Late Antiquity: A Quest for the Holy Man (Berkeley: University of California Press, 1983), xi-xii.

${ }^{12}$ James Goehring, "Imagined Landscapes," in Gender, Asceticism and Historiography: The Cultural Turn in Late Antique Studies, ed. Dale B. Martin and Patricia Cox Miller (Durham, N.C.: Duke University Press, 2005), 1-20. A similar approach to our literary sources is taken in Darlene Brooks Hedstrom, The Monastic Landscape of Late Antique Egypt: An Archaeological Construction (Cambridge: Cambridge University Press, 2017), esp. 139-179.

${ }^{13}$ Rubenson, "Formation and Reformations," 19-20.

${ }^{14}$ Among the many studies of Christian pilgrimage to the Holy Land and to Egypt, Maraval's has continued to prove immensely helpful: Pierre Maraval, Lieux Saints et Pèlegrinages d'Orient: Histoire et géographie des origins à la conquête arabe (Paris: Éditions du Cerf, 1985), esp. 81-84, noting the interconnectivity of Egypt and Palestine in pilgrim itinerary. See also Georgia Frank, Memory of the Eyes: Pilgrims to
} 
and Anastasius of Sinai's Tales of the Sinai Fathers and Edifying Tales (late seventh/early eighth centuries CE) bear witness to an interconnected and mobile monasticism of the Eastern Mediterranean in which monks moved from Egypt to Palestine with ease and frequency, the Sinai Peninsula an open door to both. ${ }^{15}$

Questions of authenticity and provenance aside, however, the Sayings confront the reader as part aphorism and part puzzle, part catechesis and part slapstick. Douglas Burton-Christie put it aptly, describing the textual world of the Sayings as "a motley band of colorful characters, wild adventures, and stinging, memorable 'one-liners."'16 As a question of genre, the Sayings muddy the waters for those who would attempt to classify hagiography neatly. ${ }^{17}$ Rapp has made a persuasive argument to read the Sayings as a continuation of the classical chreiai, a compilation of a subject's words and deeds presented, above all, for repetition by means of imitation. ${ }^{18}$ As it stands, much of the collection strikes modern readers with its humane and intuitive psychological insight. Other portions are less palatable: fantastic or violent, misogynistic or grotesque. They are often quite pithy: "Abba Amoun of Nitria came to see Abba Antony and said to him, 'Since my rule is stricter than yours, how is it that your name is better known amongst men than mine is?' Abba Anthony answered, 'It is because I love God more than you." ${ }^{19}$ Would-be scholars fare no better: "A brother said to Abba Serapion, 'Give me a word.' The old man said to him, 'What shall I say to you? You have taken the living of widows and orphans and put it on your shelves,' for he saw them full of books." 20

Dry wit from a dry land. Yet this dry land was becoming a new sort of city, and each city-at least by a certain Greek way of thinking-was a polis with its own politics. ${ }^{21}$ These new radicals of the desert were crafting a very distinct way of life. This was, in Lillian Larsen's words, "an inherently civic enterprise"-however counterintuitive and, at times, civically absurd. ${ }^{22}$ In this new city, a monk earned his or her citizenship through the symbols of suffering. As the late Veit Rosenberger pointed out, like so many

Living Saints in Christian Late Antiquity (Berkeley: University of California Press, 2000), for a discussion of Christian piety and literary reflection on pilgrimage and sainthood.

${ }^{15}$ For "the influence of nearby Egypt" on Palestinian literature, see Bernard Flusin, "Palestinian Hagiography (Fourth-Eighth Centuries)," in The Ashgate Companion to Byzantine Hagiography, vol. 1, Periods and Places, ed. Stephanos Efthymiadis (Farnham: Ashgate Variorum, 2014), 199-226, at 203-204.

${ }^{16}$ Douglas Burton-Christie, The Word in the Desert: Scripture and the Quest for Holiness in Early Christian Monasticism (New York: Oxford University Press, 1993).

${ }^{17}$ See the broad discussion of genre in Sarah Insley and Jeanne-Nicole Mellon Saint-Laurent "Biography, Autobiography, and Hagiography," in A Companion to Late Antique Literature, ed. Scott McGill and Edward J. Watts (Hoboken, N.J.: Wiley Blackwell, 2018), 373-387 (chap. 23).

${ }^{18}$ See Rapp, "The Origins of Hagiography," for her argument and the relevant bibliography.

${ }^{19}$ APalph, Amoun 1; PG 65:128; Ward, Sayings, 31; and cf. Apsys 17.3. A note on vocabulary: Abba means a male monk of some spiritual authority, usually older; old man means much the same; brother is synonymous with "monk"; and Amma means a female monk of some spiritual authority, usually older.

${ }^{20}$ APalph, Serapion 2; PG 65:415; Ward, Sayings, 227; and cf. APsys 6.16.

${ }^{21}$ For the importance of the monastic community as a Christian polis in fifth-century church and monastic histories, see Andreas Westgren, "The Monastic Paradox; Desert Ascetics as Founders, Fathers, and Benefactors in Early Christian Historiography," Vigiliae Christianae 72 (2018): 283-317.

${ }^{22}$ Larsen, "Rustic Rumination," 30. The "city in the desert" motif came quickly, at least by the early fifth century-e.g., the anonymous Historia Monachorum in Aegypto 8.20. It is apparent that this "civic enterprise" was no less evident in the desert of Palestine in the fifth and sixth centuries (as is recounted, for example, in Cyril of Scythopolis's Lives of the Monks of Palestine). Thus, we might argue that even if we imagine a sharp dividing line (which I explicitly do not) between the Egypt of the Sayings and the 
venerable founders of the city in antiquity, these monks endured the agon of exile, warfare, and self-denial in their heroic efforts to found their new polis. ${ }^{23}$ A monk's ascetic performance was, among other things, a way of staking a claim in this new enterprise, contributing to the fluid contours and boundaries of a novel social experiment. ${ }^{24}$

The monastic literature these monks (and their chroniclers) left behind gives us a very precious insight into this new sort of city. The Sayings are no exception. They reveal a community of paradox, one which emphasized both radical inclusion and stringent boundary formation. It was a community that practiced both scandalous inclusion and inflexible exclusion, demanding perfection while offering grace. In short, it was a community shot through with a dialectic of openness and closedness-a tension symptomatic of larger contradictions inherent to the Christian tradition in the late antique context. The Sayings act as a sounding board for this tension, exhorting readers to virtue while offering scandalous grace, celebrating the saint while making room for the sinner. The place of food in the Sayings provides a unique and illuminating entrance into these tensions and allows us to listen in on a formative argument in the history of Christian religious life.

\section{Eating in Egypt: Scetis, Diets, and Ancient Theory}

Most (though by no means all) of the Sayings take place in the valley of Scetis-what is now Wadi El Natrun, some sixty miles south of Alexandria in Egypt-a valley of sand and salt deposits. ${ }^{25}$ The irrigation of the Nile had not yet come as close to the wadi as it has today. In thinking of fourth-century monasticism, we must not imagine permanent walls and structures: these arose in later centuries (and some remain today). In fact, very little archaeological evidence remains from the monastic settlements of the fourth century. What the Sayings ask us to imagine instead is a motley assortment of small, makeshift cells scattered around the wadi. Some ascetics lived in caves. These peripheral

Palestine of its authors, the aim and intention of the asceticism in question and its civic resonance remain the same.

${ }^{23}$ See, inter alia, Veit Rosenberger, I pranzi dei santi: Pratiche alimentari e ascesi nel monachesimo tardoantico (Bologna: Edizione Dehoniane Bologna, 2016); Veit Rosenberger, "Competing Coenobites: Food and Drink in the Lives of Theodoretus of Cyrrhus," in Religion and Competition in Antiquity, ed. David Engels and Peter van Nuffelen (Brussels: Éditions Latomus, 2014), 173-191; and Roberto Alciati's introduction to this aspect of Rosenberger's thought in Roberto Alciati, "Asceticism between Agon and Agency," in "Zu Tisch bei den Heiligen. . .": Askese, Nahrung und Individualisierung im spätantiken Mönchtum, ed. Daniel Albrecht and Katharina Waldner (Stuttgart: Franz Steiner Verlag, 2019), 43-54.

${ }^{24}$ See further, Richard Valantasis, "A Theory of the Social Function of Asceticism," in Asceticism, ed. Vincent L. Wimbush and Richard Valantasis (Oxford: Oxford University Press, 2002), 544-552.

${ }^{25}$ On Scetis, see Hugh Evelyn-White, The Monasteries of Wadi'n Natrūn, part 2, The History of the Monasteries of Nitria and of Scetis (New York: Metropolitan Museum of Art Egyptian Expedition, 1932; repr., New York: Arno, 1973); and Lucien Regnault, The Day-to-Day Life of the Desert Fathers in Fourth-Century Egypt, trans. Étienne Poirer, Jr. (Petersham, Mass: St. Bede's, 1998). For a more expansive study of the food and economic life of early Egyptian monasticism, see Darlene Brooks Hedstrom, The Monastic Landscape of Late Antique Egypt: An Archaeological Reconstruction (Cambridge: Cambridge University Press, 2017); Ewa Wipszycka, Moines et communautés monastiques en Égypte (IVe-VIIIe siècles) (Warsaw: Journal of Juristic Papyrology, 2009); more recently, Ewa Wipszycka, The Second Gift of the Nile: Monks and Monasteries in Late Antique Egypt (Warsaw: Journal of Juristic Papyrology, 2018); and M. Mossakowska-Gaubert, "Alimentation, hygiene, vetements et sommeil chez les moins egyptiens," in La vie qoutidienne des moins en Orient et en Occident IVe-Xe siècle, ed. Olivier Delouis and M. Mossakowska-Gaubert (Athens: École française d'Athènes, 2015-2019), 23-55. 
monks, however, were not without an axis. Monks needed a place to gather as a group to celebrate the liturgy, of course, and they also needed a place to bake bread. ${ }^{26}$

This brings us to our focus: dry humor, dry land, and dry bread. Dry indeed. The monks had a word for it: paxamatia, a small loaf, about twelve ounces in weight, made of wheat, barley, or even chickpeas. ${ }^{27}$ Baked in bulk and distributed by basket, the bread was intentionally dry. (Paxamatia remains the Modern Greek word for biscotti.) A monk could store this bread for weeks or even months and would reconstitute it by dipping the loaf into water. The Sayings, however, rarely get into the pedestrian details of this process. Happily, slightly later texts provide this useful information, most importantly the monk John Cassian's De Institutis and Collationes as well as Palladius's Lausiac History, known also as the Paradise of the Holy Fathers. ${ }^{28}$

Yet the diet we get a glimpse of in the Sayings was more than bread, however foundational paxamatia was to caloric intake. Abba Arsenius, we are told, had a soft spot for dried figs and was generous in sharing when he could get them. ${ }^{29} \mathrm{He}$ was known to take small bites from ripe fruit-just a taste. ${ }^{30}$ Once, a young monk received a vision of this sweet-toothed old man in the heavenly realm with his friends and the angels. Perhaps unsurprisingly, they were eating honey cakes. ${ }^{31}$ Of course, oil was the culinary lifeblood of the Mediterranean-and these monastic communities were no exception. We read of monks who had left their cells to assist in the annual harvest near the Nile and who could expect to return with jars of oil for their labor. ${ }^{32}$ On the topic of oil, the Sayings tell us of a rather acerbic figure who preferred to concoct an oil from horseradish for use at his own table. ${ }^{33}$ We can read of stolen olives and of a fierce dispute sparked by the appeal of a small cooked fish. The latter affair ended in murder. ${ }^{34}$ The presence of a small hen or even-God forbid-a bit of veal could permanently alter one's spiritual trajectory. ${ }^{35}$ The back-and-forth is particularly fascinating, weaving

\footnotetext{
${ }^{26}$ Evidence for monastic kitchens is discussed in Brooks Hedstrom, Monastic Landscape, 223-273; and Darlene Brooks Hedstrom, "Baking Bread and Salting Fish: The Archaeology of Egyptian Monastic Kitchens and Ascetic Taste," in Knowing Bodies, Passionate Souls: Sense Perceptions in Byzantium, ed. Margaret Mullett and Susan Ashbrook Harvey (Washington, D.C.: Dumbarton Oaks, 2017), 183-206, esp. 191-204. Again, most of the material evidence discussed survives from the late fifth century and later. I believe we might presume a continuity in baking technology and procedures (in both Egypt and Palestine), though those more versed in the archaeological literature are better to judge.

${ }^{27}$ See Benedicta Ward, introduction to The Lives of the Dessert Fathers: The Historia Monachorum in Aegypto, ed. and trans. Norman Russel (Kalamazoo, Mich.: Cistercian Publications, 1981), 24-26.

${ }^{28} \mathrm{John}$ Cassian, Institutions cénobitiques, ed. and trans. Jean-Claude Guy, SC 109 (Paris: Editions du Cerf, 1965); Dominic E. Pichert, ed. and trans., Jean Cassian: Conférences, 3 vols., SC 42, 54, 64 (Paris: Editions du Cerf, 1955-1959); and Palladius, Lausiac History (CPG 6036), in The Lausiac History of Palladius, ed. C. Butler, 2 vols. (Cambridge: 1898-1904).

${ }^{29}$ APalph, Arsenios 16; PG 65:92; Ward, Sayings, 11; and cf. APsys 15.8.

${ }^{30}$ APalph, Arsenios 19; PG 65:92; Ward, Sayings, 11; and cf. APsys 4.16.

${ }^{31}$ APalph, Arsenios 38; PG 65:104-105; and Ward, Sayings, 18.

${ }^{32}$ APalph, Benjamin 1; PG 65:144; Ward, Sayings, 43; and cf. APsys 17.24. See Ewa Wipszycka, Moines et communautés monastiques, 486-489, for a discussion of monastic labor in agricultural production.

${ }^{33}$ APalph, Benjamin 3; PG 65:144-145; and Ward, Sayings, 43-44.

${ }^{34}$ Respectively: APalph, Gelasius 2; PG 65:148; Ward, Sayings, 46-47; with APalph, Gelasius 3; PG 65:148-149; and Ward, Sayings, 47-48. On the prevalence of fish in the monastic diet (prohibitions notwithstanding), see Sarah J. Clackson, "Fish and Chits: the Syndodontis schall," Zeitschrift für ägyptische Sprache und Altertumskunde 129, no. 1 (2002) 6-11.

${ }^{35}$ Respectively: APalph, Epiphanius 4; PG 65:164; Ward, Sayings, 57; with APalph, Theophilus 3; PG 65:200; Ward, Sayings, 81; and cf. APsys 4.76.
} 
a tapestry of contrasts. We are told that one old man asked for a cup of fruit punch on his deathbed, ${ }^{36}$ whereas Abba Euprepius advised a follower to eat only straw. ${ }^{37}$

But these are interesting exceptions to a generally pedestrian diet. The diet of a Coptic monk was in most respects quite similar to that of a given Egyptian peasant: bread and salt, of course, and a stew of lentils or porridge of grain. ${ }^{38}$ The Sayings speak of onions, herbs, small greens, and cucumbers. It is a diet of staples, a list of ingredients much less radical than other facets of life in this desert polis (see Table 1).

Table 1: Food in the Alphabetic and Systematic Collections of the Apophthegmata Patrum. ${ }^{39}$

This list contains food mentioned at least once within both the Greek Alphabetical and Systematic Collections of the Apophthegmata Patrum. I have endeavored to be exhaustive, though it is certainly possible that some words have escaped my notice.

״̈ $\boldsymbol{\alpha} \boldsymbol{\alpha}$ (halas) salt; when mixed with water, this becomes the "sauce" found in several Sayings.

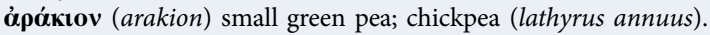

$\dot{\boldsymbol{\alpha} \theta \boldsymbol{\eta} \rho \boldsymbol{\alpha}}($ athèra) a broth-like substance whose exact definition remains elusive. Perhaps a soup or a porridge. In the Sayings, this is at times mixed with $\boldsymbol{\mu} \boldsymbol{v} \xi \boldsymbol{\alpha}$ (see below).

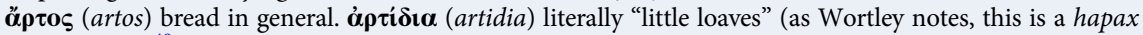
legomena). ${ }^{40}$

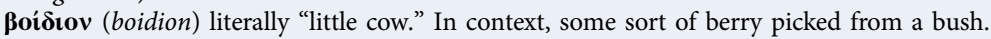

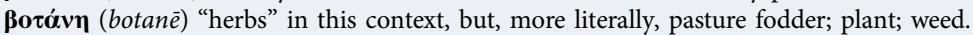

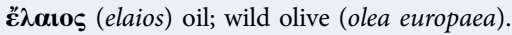

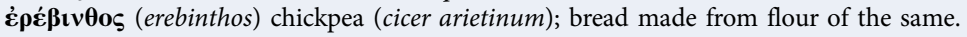

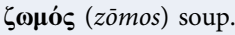

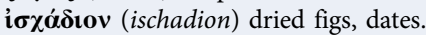

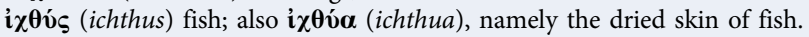

кодо́кvvөоธ (kolokunthos) gourd.

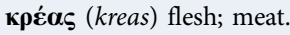

крí日ıvos (krithinos) barley.

кро́ $\mu$ йov (krommuon) onion (allium cepa); a shallot.

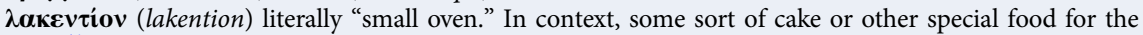
ill. $^{41}$

\footnotetext{
${ }^{36}$ APalph, Macarius 8; PG 65:265-267; and Ward, Sayings, 129.

${ }^{37}$ APalph, Euprepius 4; PG 65:172; Ward, Sayings, 62; and cf. APsys 21.66.

${ }^{38}$ The study of diet in the late antique Mediterranean has seen a recent growth of sophisticated and interdisciplinary approaches. Among others, readers should be directed to Michael Decker, Tilling the Hateful Earth: Agricultural Production and Trade in the Late Antique East (Oxford: Oxford University Press, 2009); R. S. Bagnall, Egypt in the Byzantine World, 300-700 (Cambridge: Cambridge University Press, 2007); and Peregrine Horden and Nicholas Purcell, The Corrupting Sea: A Study of Mediterranean History (Hoboken, N.J.: Wiley-Blackwell, 2000). Brooks Hedstrom offers a concise list of common monastic foods found in monastic literary sources outside of the Sayings in Brooks Hedstrom, "Baking Bread and Salting Fish," $188-191$.

${ }^{39}$ It is possible that some of the ambiguity around these food terms could be cleared away by comparing individual sayings that appear in what survives of our Coptic versions of the Sayings, in particular the Sahidic collection reproduced in M. Châine, ed., Le manuscript de la version copte en dialect sahidique des "Apophthegmata Patrum," Bibliothèque d'ètudes coptes 6 (Cairo: Institut Français d'Archéologie Orientale, 1960). A helpful third source would be an analysis of the many food references found in the Coptic Rules attributed to Shenoute (348-466 CE) and his monasteries, recently translated: Bentley Layton, trans., The Canons of our Fathers: Monastic Rules of Shenoute (Oxford: Oxford University Press, 2017). Layton has laid out a similar table of the foods in Bentley Layton, "Social Structure and Food Consumption in an Early Christian Monastery," Le Muséon 115 (2002): 25-55, at 40-42.

${ }^{40}$ Wortley, The Book of the Elders, 50n6.

${ }^{41}$ See Wortley, The Book of the Elders, 51n8; and Guy, Les Apophtegmes des Pères (SC 387), $221 \mathrm{n} 1$.
} 
$\lambda \boldsymbol{\alpha} \boldsymbol{\alpha} \boldsymbol{\alpha} \boldsymbol{\alpha} \mathbf{o v}$ (lachanon) garden herb; vegetable.

$\lambda \varepsilon \pi \tau \mathbf{\alpha} \lambda \boldsymbol{\alpha} \chi \boldsymbol{\alpha} \boldsymbol{\alpha} \mathbf{o v}$ (leptolachanon) "small plant"; Ward translates as "chicory leaves."

$\lambda \imath \mathbf{v o ́} \boldsymbol{\pi} \boldsymbol{\varepsilon} \boldsymbol{\rho} \boldsymbol{\mu} \boldsymbol{\alpha}$ (linospermos) linseed, also known as flaxseed (Linum usitatissimum). Mentioned as an oil.

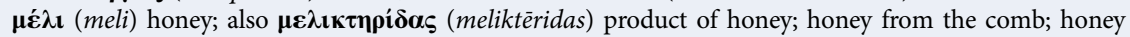
cakes.

$\mu \hat{\eta} \lambda \mathbf{o v}(m \bar{e} l o n)$ apple; any tree fruit including apricot, rose apple, citron; another catchall for "fruit." $\boldsymbol{\mu o \sigma} \chi \mathbf{i} \mathbf{0}$ (moschion) young calf; veal.

$\boldsymbol{\mu} \boldsymbol{v} \boldsymbol{\xi} \boldsymbol{\alpha}$ (muxa), a fruit (sebesten, cordia myxa); in general, a pulpy sweet substance. Also known as the Sapistan Plum.

$\boldsymbol{\mu \nu} \xi \dot{\boldsymbol{\alpha}} \boldsymbol{\rho} \boldsymbol{\iota} \mathbf{0} \boldsymbol{v}$ (muxarion) diminutive of $\boldsymbol{\mu} \boldsymbol{v} \boldsymbol{\xi} \boldsymbol{\alpha}^{42}$

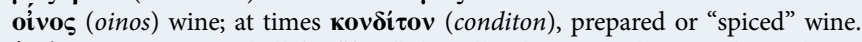

ó $\boldsymbol{x} \boldsymbol{\omega} \boldsymbol{\rho} \boldsymbol{\alpha}($ opōra) a catchall for "fruit"; literally, the season between late July and the end of September.

óyópııv (opsarion) literally, a small fish; a cooked fish; a fish meal; fish pudding; fish sauce.

$\boldsymbol{\pi} \boldsymbol{\alpha} \boldsymbol{\sigma} \boldsymbol{\tau} \mathbf{\imath} \boldsymbol{\lambda} \boldsymbol{o v}$ (pastilon) remains something of a mystery. A sort of sweet drink from a mix of fruit and water

(Ward translates this as "sherbet").

$\pi \boldsymbol{\alpha} \boldsymbol{\alpha} \boldsymbol{\alpha} \boldsymbol{\mu} \boldsymbol{\alpha} \tau \boldsymbol{\alpha} \boldsymbol{\alpha}$ (pachamatia) dried bread.

$\pi \varepsilon \tau \boldsymbol{\varepsilon} \iota \mathbf{v o ́} \varsigma$ ( petēnos) literally "winged"; bird; fowl.

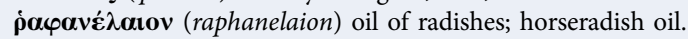

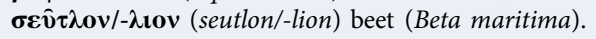

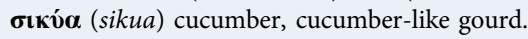

$\boldsymbol{\sigma} \boldsymbol{\imath} \lambda \boldsymbol{\imath} \boldsymbol{\gamma} \boldsymbol{\gamma}$ íov (silignion) known as "winter wheat" (Lat. siligo).

бîtos (sitos) a measure of grain, either wheat or barley; food made from grain; bread; "food" as opposed to "drink."

$\boldsymbol{\sigma} \boldsymbol{\kappa} i \boldsymbol{\lambda} \lambda \boldsymbol{\alpha}$ (skilla) squill, or bitter onion (Urginea maritima).

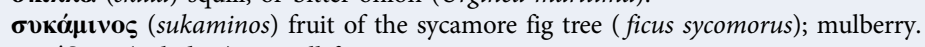

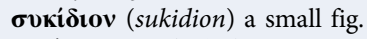

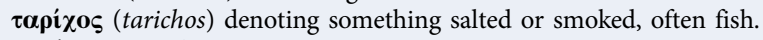

topós (turos) cheese.

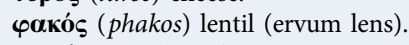

بotvíkıv (phoinikion) dates.

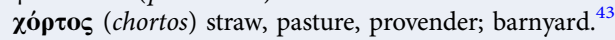

It is a list of (mostly) simple ingredients, to be sure. Simplicity as a virtue, however, was a common component of monastic discourse. The idea that Christian monastic life would be marked by simplicity in food and drink gained great popularity in the literature of the Egyptian desert. But this was not a wholly Christian idea. Few things turn out to be novelties. That "simple" equaled "good" was a trope preceding this Christian experiment and existing contemporaneously outside of it. ${ }^{44}$ Moralists praised the ancient Spartans for the austerity of their tables. ${ }^{45}$ Roman Stoics waxed nostalgic for the simple diets of their republican ancestors, whose virtue in governance was sustained

\footnotetext{
${ }^{42}$ Used medicinally in APsys 4.78.

${ }^{43}$ On early monastic literature concerning those who ate straw, grass, or whatever else grew in the wild,

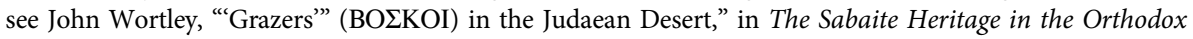
Church from the Fifth Century to the Present, ed. Joseph Patrich (Leuven: Peeters, 2001), 37-48, 41-42 on Egypt.

${ }^{44}$ For a brief introduction to the religious and philosophical contexts in which late antique Christians fasted, see Veit Rosenberger, "Divine Diets: Food and Drink of Early Monks," in Norm and Exercise: Christian asceticism between late antiquity and early middle ages, ed. Roberto Alciati (Stuttgart: Franz Steiner Verlag, 2018), 127-138; and Jan N. Bremmer, "Ancient Teetotalers: From Homer via the Early Christian Eucharist to Late Antique Monks," in Zu Tisch, ed. Albrecht and Waldner, 69-80.

${ }^{45}$ See, e.g., Plutarch, Institutia Laconica 1-3, 13.
} 
by ignoring foreign imports and eating only the fruit of their labor. ${ }^{46}$ Commenting on the place of food in the Stoic Seneca's Epistulae Morales, Christine Richardson-Hay writes that, for Seneca, food served as a distinct moral "language' with its own resonance, insight, judgment and resolution." 47 The same holds true throughout the Sayings.

Moreover, this simplicity that early Egyptian monks both presumed and extolled had contemporary science behind it. The link between food and drink and the heat of the blood and the production of semen was obvious among the educated and philosophically inclined. ${ }^{48}$ This scientific consensus mapped quite well onto certain religious impulses. In North Africa, Tertullian would encourage his coreligionists to eat simple and dry foods. Complexity and moistness fueled the passions of lust and anger. A dry corpse, after all, would be an easier thing for God to resurrect! ${ }^{49}$ The Sayings share this sentiment as well. The great Abba Anthony expresses it in his own way:

Abba Anthony said, "I believe that the body possesses a natural movement, to which it is adapted, but which it cannot follow without the consent of the soul; it only signifies in the body a movement without passion. There is another movement, which comes from the nourishment and warming of the body by eating and drinking, and this causes the heat of the blood to stir up the body to work. That is why the apostle said, 'Do not get drunk with wine for that is debauchery.' (Ephes. 5.18) And in the Gospel the Lord also recommends this to his disciples: 'Take heed to yourselves lest your hearts be weighed down with dissipation and drunkenness"' (Luke 21:34). ${ }^{50}$

Eat only a little, eat simply, and eat what is dry. This would clear the mind, check the libido, and drain anger from the heart. Amma Syncletica-a desert mother-would

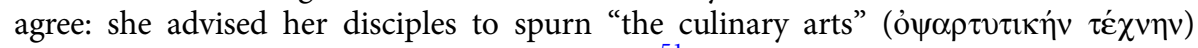

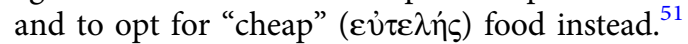

The relative simplicity of this advice stands in some contrast to the contemporary and sophisticated ascetic theories found in the works of Evagrius Ponticus (ca. 345-399 CE).

\footnotetext{
${ }^{46}$ See, e.g., Pliny the Elder, Naturalis Historia, bk. 18 passim. Nicholas Purcell offers a guide to this "nostalgia" for the diet of the past. See Nicholas Purcell, "The Way We Used to Eat: Diet, Community, and History at Rome," American Journal of Philology 124, no. 3 (Autumn 2003): 329-358.

${ }^{47}$ Christine Richardson-Hay, "Dinner at Seneca's Table: The Philosophy of Food," Greece and Rome, 2nd ser., 56, no. 1 (April 2009): 71-96, at 74-75. See Seneca's description of his own simple diet at Epistulae Morales ad Lucilium 83.6, 87.3, 108.15.

${ }^{48}$ On this topic, see Kyle Harper, From Shame to Sin: The Christian Transformation of Sexual Morality in Late Antiquity (Cambridge, Mass.: Harvard University Press, 2013), 56-60; and Teresa Shaw, The Burden of the Flesh: Fasting and Sexuality in Early Christianity (Minneapolis: Fortress, 1998), 27-68. Dana Robinson examines John Chrysostom's homiletic exhortations toward simple eating (and the scientific theory behind it) in Food, Virtue, and the Shaping of Early Christianity (Cambridge: Cambridge University Press, 2020), 29-39. See also Peter Brown's foundational treatment in The Body and Society: Men, Women, and Sexual Renunciation in Early Christianity (New York: Columbia University Press, 1988), 9-13, 17-21.

${ }^{49}$ See the discussion of this aspect of Tertullian's thought in Rosenberger, "Divine Diets," 133-135. For Tertullian's thoughts on the ease with which light, dry bodies will rise, see Tertullian, De ieiunio adversus psychicos 17.

${ }^{50}$ APalph, Anthony 22; PG 65:84; Ward, Sayings, 6; and cf. APsys 5.1. See also APsys 1.4 and 4.55 for the promotion of a dry diet.

${ }^{51}$ APalph, Syncletica, 4; PG 65:421; and Ward, Sayings, 231.
} 
In his On the Vices Opposed to the Virtues, Evagrius would center gluttony as the cornerstone of the sinful condition and weave its causes and effects through an advanced theory of the human person and its relation to desire. ${ }^{52}$ John Cassian's debt to Evagrius is evident in his Institutes and Conferences, balancing as he does the vices of gluttony and its consequence, lust, with the recognition (as Theresa Shaw has noted) that such impulses are nevertheless "essential for sustaining human life." 53 Even prior to these men, Athanasius of Alexandria (295/299-373) would offer his own sustained vision of the intricate details of ascetic "technology," a vision he expressed in his letters as well as in his mythic-creation: the drama of the Life of Antony. ${ }^{54}$

All three of these men were deeply rooted in the monastic culture of Egypt. Yet their attempts at systematizing a synthesis of Greek philosophy (mostly Neo-Platonic, though to some degree Stoic) with radical biblical thinking only accents the eccentric nature of the Sayings when viewed in comparison. Taken as a whole, the Sayings operate on an axis of blunt opposites: mercy and judgement, shame and glory. Their paradoxes betray a Christian tradition not fully at home with the theoretical masterpieces of its most talented thinkers. It is easy to imagine how the Sayings, recited and memorized in monasteries across the Mediterranean, would have a greater impact on the vast majority of monks whose literacy and education would not allow them meaningful access to the elaborate works of their more famous literati.

\section{Eating: Rigor and Relaxation}

The monks in the Sayings fast, and this austerity touches almost every page. A few representative examples will be helpful. Abba Arsenius's disciples would bring him a basket of dried bread at the beginning of the year, and when they returned at the end of the year, he would feed them from the same basket. ${ }^{55}$ Abba Amoun was said to have hardly touched the unbaked wheat that was brought to him. The fact that he would lose it, leave it, or let it spoil was a cause of no small anxiety to the hungrier among his disciples. ${ }^{56}$ When the monk Isaiah ate lentils, he did not bother to cook them. ${ }^{57}$ Abba Isaac would gather ashes from church incense and mix them with his bread. ${ }^{58}$ Abba Pior would not eat unless he was on his feet and walking, lest he make "an occupation" out of mealtime. ${ }^{59}$

These were individual tactics in a war waged against the body-weary old men wearing down their flesh. A monk had to die before he could live. Abba John, called the

\footnotetext{
${ }^{52} \mathrm{~A}$ new critical edition is now found in Charles Antoine-Fogielman, A Euloge: Les vices opposés aux vertues, SC 591 (Paris: Éditions du Cerf, 2017). For an introduction to the work of Evagrius, see A. M. Casiday, Evagrius Ponticus (Abingdon: Routledge, 2007). I owe a great debt as well to Shaw, The Burden of the Flesh, 129-130, 139-160, and see especially her analysis of Evagrius's treatment of desire-a movement from ascetically obtained apatheia to apage to gnosis-at 155-158.

${ }^{53}$ See Shaw, The Burden of the Flesh, 112-124, 145-146 (quote at 146). On Cassian's debt to Evagrius in the formation of a monastic literary culture, see, inter alia, Steven D. Driver, John Cassian and the Reading of Egyptian Monastic Culture (London: Routledge, 2002).

${ }^{54}$ See, most importantly, David Brakke, Athanasius and the Politics of Asceticism (Oxford: Clarendon, 1995): his discussion of Athanasius's "ascetic program" is found throughout 143-244.

${ }^{55}$ APalph, Arsenius 17; PG 65:92; Ward, Sayings, 11; and cf. APsys 4.4.

${ }^{56}$ APalph, Amoun 2; PG 65:128; and Ward, Sayings, 31-32.

${ }^{57}$ APalph, Isaiah 6; PG 65:181; and Ward, Sayings, 70.

${ }^{58}$ APalph, Isaac 6; PG 65:225; and Ward, Sayings, 100.

${ }^{59}$ APalph, Pior 2; PG 65:373; Ward, Sayings, 199; and cf. APsys 4.42.
} 
Dwarf, used an elegant (and civic) analogy: "If a king wanted to take possession of his enemy's city, he would begin by cutting off the water and the food and so his enemies, dying of hunger, would submit to him." ${ }^{60}$ Abba Alonius once said: "If I had not destroyed myself completely, I should not have been able to rebuild and shape myself again." $^{61}$

On the other hand, the Sayings bear witness to a more moderate school of thinking on this issue of food and fasting-humane advice, easier on the ear:

Abba Joseph asked Abba Poemen, "How should one fast?" Abba Poeman said to him, "For my part I think it is better that one should eat every day, but only a little, so as not to be satisfied." Abba Joseph said to him, "When you were younger, did you not fast two days at a time, abba?" The old man said: "Yes, even for three days and four and the whole week. The Fathers tried all this out as they were able and they found it preferable to eat every day, but just a small amount. They left us this royal way, which is light. ${ }^{62}$

Fasting, after all, was no guarantee of piety. Amma Theodora observed that even the demons fasted. ${ }^{63}$ Abba Hyperechius put it candidly: "It is better to eat meat and drink wine than to eat the flesh of one's brother through slander." ${ }^{64}$ Thus, one senses a special tension in the atmosphere of the weekly communal meals in Scetis. On Sundays, monks who had been practicing their own private rules found themselves surrounded by their brothers, eating in public. These so-called agape meals were potential arenas for scandal, judgement, arrogance, and shame-the plate of each a reflection of the soul. ${ }^{65}$

A monk's reputation as an ascetic, moreover, could gain him fanfare that he did not want. In this case, certain monks knew how to use prejudice and expectation to their own advantage:

Another time, another magistrate came to visit [Simon]. The clergy went on ahead and said to the old man, "Abba, get ready, for this magistrate has heard of you and is coming for your blessing." So he said, "Yes, I will prepare myself." Then he put on a rough habit and taking some bread and cheese in his hands he went and sat in the doorway to eat it. When the magistrate arrived with his suite and saw him, he despised him and said, "Is this the anchorite of whom we have heard so much?" and they went away at once. ${ }^{66}$

One wonders where he came by the cheese!

But here I want to return to Abba Alonius's dictum ("If I had not destroyed myself completely," et cetera). This monastic self-destruction was a very public project. Abba Alonius's practice of tearing down and renewal merits a closer translation. What Ward

\footnotetext{
${ }^{60}$ APalph, John the Dwarf (John Colobos) 3; PG 65:205; Ward, Sayings, 86; and cf. APsys 4.20.

${ }^{61}$ APalph, Alonius 2; PG 65:133; and Ward, Sayings, 35.

${ }^{62}$ APalph, Poemen 31; PG 65:329; Ward, Sayings, 171-172; and cf. APsys 10.61.

${ }^{63}$ APalph, Theodora 6; PG 65:203; and Ward, Sayings, 84.

${ }^{64}$ APalph, Hypherechius 4; PG 65:429; and Ward, Sayings, 238.

${ }^{65}$ E.g., the concerns expressed in APalph, Siseos 2; PG 65:392; and Ward, Sayings, 213. See the comments

in Harmless, Desert Christians, 176 and 180.

${ }^{66}$ APalph, Simon 2; PG 65:412-413; and Ward, Sayings, 225. A Simon is found evading notice as well in APsys 8.22.
} 
renders with two English verbs ("rebuild and shape myself") is a single Greek verb,

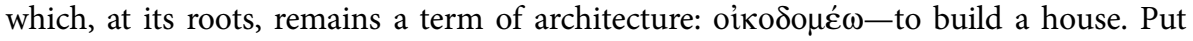
literally, Abba Alonius claims that the destruction of his person was a prerequisite

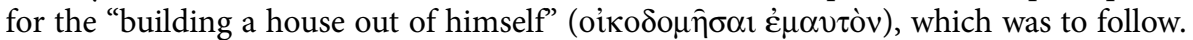
This image of architectural spirituality had precedent: Paul and other New Testament authors would use it in a similar fashion. ${ }^{67}$ Later monastic writers, such as Anastasius of Sinai, would continue the tradition. ${ }^{68}$

Alonius was building himself up as a house; he was founding a community from his body. This was a public, performative act with very eager audiences. In such acts, these Egyptian monks were defining the boundaries of Christian community with and within their own bodies, transforming their flesh into living laws of ascetic praxis. ${ }^{69}$ Once, when Amma Sarah served visiting monks a bowl of fruit, she took a look at the remains. The monks had eaten the bad fruits and left the good fruits in the bowl. Their performance was immediately commended with these words: "You are the true monks of Scetis." 70 They had gained their citizenship in the eyes of their watchful host.

It is an anthropological truism that communities state and reiterate difference in many ways, not least taboos concerning food and drink. ${ }^{71}$ You are what you eatand the same is perhaps true about what you do not eat as well as how you eat. ${ }^{72}$ "Food," as Dana Robinson writes, "unites personal identity with communal experience." 73 That these desert Christians would craft a community by means of alternating prohibition and permission vis-à-vis food is itself no novelty. Much of the New Testament bears witness to an ongoing dispute about who can eat what with whom. ${ }^{74}$ Christians, moreover, codified their status as such through a meal of bread

\footnotetext{
${ }^{67}$ E.g., 2 Cor. 5:1, 10:8, 12:19, 13.10; and Rom. 14:19, 15:2; 1 Cor. 3:9, 14:3, 5, 12, 26. Paul's usage, for example, reminds us of the relationship between "edifice" and "edification" in English.

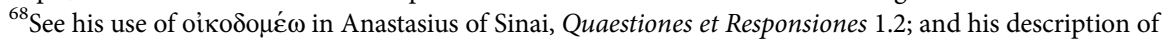
the Christian as "a house of Christ" in Anastasius of Sinai, Viae Dux 2.6, 20-21.

${ }^{69}$ Here Rosenberger's phrasing of the Christian "semiotics of food" seems quite apt. Borrowing from Lévi-Strauss, he argues that food in monastic discuss is a "floating signifier," whose meaning remains contested and malleable. Rosenberger, "Divine Diets," 128-130. For a similar discussion, see also Valantasis, "Theory of the Social Function."

${ }^{70}$ APalph, Sarah 8; PG 65:421; and Ward, Sayings, 230.

${ }^{71}$ There is now no shortage of literature on food, anthropology, and religion. A helpful starting point can be found in Corrie E. Norman, "Food and Religion," in The Oxford Handbook of Food History, ed. Jeffrey M. Pilcher (Oxford: Oxford University Press, 2012), 409-427. A summary of much of this literature is offered in Robinson Food, Virtue, and the Shaping of Early Christianity, 8-10. Peter Garnsey puts it succinctly: "Food is often at the center. . because the food we eat and the way we eat it are an integral part of social behavior and cultural patterns." Peter Garnsey, Food and Society in Classical Antiquity (Cambridge: Cambridge University Press, 1999), 80.

${ }^{72}$ On the ubiquity of this sentiment in cultures throughout the globe, see Paul Rozin, "Social and Moral Aspects of Food and Eating," in The Legacy of Solomon Asch: Essays in Cognition and Social Psychology, ed. Irvin Rock (Hillsdale, N.J.: Lawrence Erlbaum Associates, 1990), 97-110, esp. 101-102.

${ }^{73}$ Robinson, Food, Virtue, and the Shaping of Early Christianity, 4.

${ }^{74}$ See, e.g., Matt. 9:11; Mark 7:14-23; Acts 10-11:18; Gal. 2; 1 Cor. 8; 17-34; and Rom. 14:13-23, inter alia multa. For a discussion of early Christian eating practices, see Dennis E. Smith, From Symposium to Eucharist: The Banquet in the Early Christian World (Minneapolis: Augsburg Fortress, 2003); Matthias Klinghardt, Gemeinschaftsmahl und Mahlgemeinschaft: Soziologie und Liturgie frühchristlicher Mahlfeiern (Tübingen: A. Francke Verlag, 1996); and Andrew McGowan, "Food, Ritual, and Power," in A People's History of Christianity: Late Ancient Christianity, ed. Virginia Burrus (Minneapolis: Augsburg Fortress, 2005), 145-164. Of course, food prohibitions in the Hebrew Old Testament merit a bibliography of their own.
} 
and wine- - a food and a drink that caused no end of scandal among these early monastics. ${ }^{75}$ In this case, we might speculate that the sacred meal was sacred inasmuch as it was constituted of what was always dangerous and (often) forbidden. The communal meal erased differences: strict ascetics were forced to share a cup with more lax participants. In this case, loss of distinction could lead to an increase in open conflict. ${ }^{76}$

\section{Irreconcilable Differences? Renunciation and Charity}

Even as a literary corpus, conflict abounds in the Sayings. To highlight the tension in these texts, we can focus more closely on the intersection of two key monastic virtues. The first I have just discussed-renunciation, asceticism, the fast. The other, however, was equally important-namely, hospitality and care. The Sayings never reconcile these two. It is even more striking given the fact that later monks and Christian literati did not seem to alter or edit these "portraits" to reach a more satisfying synthesis. Regarding these two priorities, the Sayings read like an argument, a debate on the hierarchy of values in this new city in the desert. This is a tension, as I have already suggested, that we find throughout the Christian tradition (at times with surprising results). But first, it is worth looking at a few examples of this tension in the Sayings.

The Sayings provide ample evidence for an approach to hospitality that placed welcoming the guest above one's fasting rule. ${ }^{77}$ There was room for flexibility, with caution: "A brother questioned Abba Matoes, 'What ought I to do when a brother comes to see me and it is a fast day, or in the morning? This worries me.' The old man said to him, 'If you don't fuss about it and simply eat with the brother, that is all right, but if you are not expecting anyone and you eat, that is your own will." 78 Cassian, for his part, was impressed by an old man who always broke the fast for the sake of hospitality. The old man had his own biblical precedent. "Can the wedding guests fast," he asked, "while the bridegroom is with them?"79

Still, flexibility for the sake of hospitality could call for the cleverest of calculations:

It was said of Abba Paphnutius that he did not readily drink wine. One day he found himself on the road facing a band of robbers who were drinking wine. The captain of the band was acquainted with him and knew that he did not drink wine. Seeing how weary he was, he filled him a cup of wine and holding his sword in his hand he said to him, "If you do not drink this, I will kill you." So the old man, knowing that he was fulfilling the commandment of God and in order to win the confidence of the robber, took the cup and drank it. Then

\footnotetext{
${ }^{75}$ On Eucharistic practice in these communities - and on the question of eucharists without wine-see Bremmer, “Ancient Teetotalers," 76-77.

${ }^{76}$ An observation owed to René Girard, among others. See, e.g., René Girard, Violence and the Sacred, trans. Patrick Gregory (Baltimore: The John Hopkins University Press, 1972), passim, but especially all of chap. 5. See also Douglas A. Marshall, "Temptation, Tradition and Taboo: A Theory of Sacralization," Sociological Theory 28, no. 1 (2010): 81-107. Booth discusses the problem of the eucharist in fourth-century monastic contexts, especially as it related to ecclesiastical authority and the integration of monks into the broader church, in Phil Booth, Crisis of Empire: Doctrine and Dissent at the End of Late Antiquity (Berkeley: University of California Press, 2014), 7-15.

${ }^{77}$ See the comments on charity and hospitality in Ward, The Lives of the Desert Fathers, 35-38; and Harmless, Desert Christians, 204-205.

${ }^{78}$ APalph, Mateos 6; PG 65:291; and Ward, Sayings, 143.

${ }^{79}$ APalph, Cassian 1; PG 65:244; Ward, Sayings, 113 (quoting Mark 2: 19-20); and cf. APsys 13.2.
} 
the captain asked his forgiveness, saying, "Forgive me, abba, for I have made you unhappy." But the old man said, "I believe that, thanks to this cup, God will have mercy on you now and in the age to come." Then the robber captain said, "Have confidence in God that from now on I shall not harm anyone." So the old man converted the whole band by giving up his own will for the Lord's sake. ${ }^{80}$

Having been robbed himself, one memorable Saying tell us, Abba Sisoes dug through dung to find grain to eat and distributed this provender fairly. ${ }^{81}$

Others were less sanguine about hospitality. Monks, it seemed, were looking for any excuse to leave their cells. In this light, Abba Achilles appears as an absolutist: "Abba Bitimius said, 'One day when I was going down to Scetis, someone gave me some fruit to take to the old men. So I knocked on the door of Abba Achilles' cell, to give him some. But he said to me, "Brother, from now on I do not want you to knock on my door with any sort of food and do not go to knock at any other cells either." So I withdrew to my cell, and took the fruit to the church." 82

Achilles was not content to shut the world out by means of a cell, either. He had a habit of inviting himself into other monks' cells in order to give their diet a once-over. ${ }^{83}$ Achilles was scandalized when he caught a young monk dipping his bread in salted water. In Achilles's estimation, this was not a banality: it was a sauce. "If you want to eat sauce," he told the young monk, then he should go back to civilization. ${ }^{84}$ For his part, Abba Isidore had biblical justification in refusing an invitation to eat with his brothers. "Adam," he said "had been deceived by food and thereby kicked out of paradise." 85

The general aura of severity, however, could diminish when an old monk lay on his sick bed. Amma Syncletica's advice was matter-of-fact: "While you are young and healthy, fast, for old age with its weakness will come." ${ }^{\text {"T }}$ The Sayings tell us that both Abba Eulogius and Abba Poemen recommended bringing hearty food and a skin of wine to the infirm and bedridden. ${ }^{87}$ This was comfort food, in the sense that we understand it. ${ }^{88}$ Yet one monk's hospitality was another old man's final temptation:

\footnotetext{
${ }^{80}$ APalph, Paphnutius 2; PG 65:377; Ward, Sayings, 202; and cf. APsys 17.15.

${ }^{81}$ APalph, Sisoes 31; PG 65:401-404; and Ward, Sayings, 218-219.

${ }^{82}$ APalph, Achilles 2; PG 65:124; and Ward, Sayings, 29.

${ }^{83}$ The Canons of Shenoute contain a program for the regimented inspection of individual dwellings in search for illicit eating activity. See Layton, "Social Structure and Food Consumption," 51.

${ }^{84}$ APalph, Achilles 3; PG 65:124; Ward, Sayings, 29; and cf. APsys 4.10. Achilles's rebuke is literally: "Go

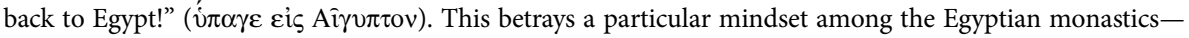
namely, that by leaving farms and cities they had left the land altogether. See the analysis of prohibitions against extra seasonings and sauces in Shenoute's Canons in Layton, "Social Structure and Food Consumption," 37, esp. n58.

${ }^{85}$ APalph, Isidore the Priest 1; PG 65:233-236; Ward, Sayings, 106; and cf. APsys 4.23.

${ }^{86}$ APalph, Syncletica 15; PG 65:425; and Ward, Sayings, 233-234.

${ }^{87}$ Respectively: APalph, Eulogius 1; PG 65:169-172; Ward, Sayings, 60-61; with APalph, Poemen 4; PG 65:317-320; and Ward, Sayings, 164-165. On sickness more broadly in the Apophthegmata, see Sean Moberg, "The Use of Illness in the Apophthegmata Patrum," Journal of Early Christian Studies 26, no. 4 (Winter 2018): 571-600.

${ }^{88}$ The Canons of Shenoute share a similar concern for feeding the frail and thus allow us to confirm that this theme in the Sayings can certainly be confirmed in contemporary Egyptian practice. See Layton, "Social Structure and Food Consumption," 38-39.
} 
They said there was a certain old man in the Thebaid, Abba Antionus, who did many good works while he was young, but when he grew old he became sick and blind. Since he was ill, the brethren took great care of him, even putting his food in his mouth. They asked Abba Aio what would come of this solicitude. He replied, "I tell you, if when he eats even one date he does so eagerly and willingly, God takes that away from his works; but if he receives it reluctantly and unwillingly, God will keep his works intact, since he has to do this against his will. The brethren will receive their reward." 89

No rest for the weary. Abba Theodore, so the story goes, would keep the food given to him from the first visitor and serve it to the second. The second visitor's food he would keep for the third. In this way, Theodore could practice both hospitality and restraint. ${ }^{90}$ Perhaps for the old monks, the special attention merited in dying was a great trial after a life of littler trials. Charity and asceticism remained in conflict even to the end. This may help to make some sense of the rather counterintuitive Saying of Abba James: "Abba James said, 'It is better to receive hospitality than to offer it." 91 Some acts of humility proved inevitable.

Some old men, known both for their radical hospitality and their strict rule, could find themselves between a rock and hard place-especially in public gatherings. The potential for scandal was palpable. Abba Poemen's strategy perhaps best captures this conflict:

It happened that several Fathers went to the home of a friend of Christ; among them was Abba Poemen. During the meal, meat was served and everyone ate some except Abba Poemen. The old men knew his discretion and they were surprised that he did not eat it. When they got up, they said to him, "You are Poemen, and yet you behaved like this?" The old man answered, "Forgive me, my Fathers; you have eaten and no-one is shocked; but if I had eaten, since many brothers come to me, they would have suffered harm, for they would have said Poemen has eaten meat; why should not we eat it ourselves?" So they admired his discernment. $^{92}$

It was a tri-partite calculation. The rule demanded he refrain, charity demanded he participate, and a keen awareness of his public demanded he err on the side of caution.

To eat and drink in public, as I have argued, was a performative act-a declaration of a monk's spiritual state, however complex the calculations. This was true perhaps most particularly of wine. ${ }^{93}$ On this topic, the Sayings provide a tour de force of differing opinions. Abba Poemen was asked about a monk who drank wine. His answer was frank: "Wine is not for monks." ${ }^{\prime}$ On the other hand, we read: "Then Abraham, his disciple, asked Abba Sisoes, 'If the gathering takes place on Saturday or Sunday and a

\footnotetext{
${ }^{89}$ APalph, Aio, 1; PG 65:136; and Ward, Sayings, 37.

${ }^{90}$ APalph, Theodore of Pherme 26; PG: 65:193; and Ward, Sayings, 77-78.

${ }^{91}$ APalph, James 1; PG 65:232; and Ward, Sayings, 104.

${ }^{92}$ APalph, Poemen 170; PG 65:364; and Ward, Sayings, 190.

${ }^{93}$ For a concise introduction to the problems of wine-drinking among other religious and philosophical communities, see Bremmer, "Ancient Teetotalers," 69-71.

${ }^{94}$ APalphi, Poemen 19; PG 65:325; and Ward, Sayings, 169. This is, of course, the same Poemen who encouraged bringing wine to an ailing monk (note 87 above).
} 
brother drinks three cups of wine, is that not a lot?' The old man said, 'If Satan is not in it, it is not much." 95 It is hard to take this Sisoes at his word: elsewhere in the Alphabetical Collection, we find him on a mountaintop with his fellow monks and a bottle of wine. Sisoes gladly received the first cup. His companion poured him a second cup-and he drank this. His companion began to pour a third, but Sisoes stopped him. "Don't you know," he asked, "that the third cup is from Satan?"96 Another elder, however, told his disciples that they could indeed drink up to three cups of wine "if it is unavoidable." 97 Was three the limit? An anonymous elder said, "Let not a monk who drinks more than three cups of wine pray for me." "98 Abba Xoius made his own contribution to this numerical calculation. A brother asked him a question, saying, "If I drink three cups of wine, is that a lot?" Xoios answered, "If the devil did not exist, it would not be a lot. But since he exists, it is a lot." 99

\section{An Argument in the Desert}

Food abounds in the Apophthegmata Patrum - it stands as a practical necessity and a symbol of sanctity. The material is rich, and I hope these few examples give a sufficient taste of the suggestive contradictions inherent in the text. Certainly, more can be said about food in monastic literature in Egypt. The fifth and sixth centuries, moreover, bring us our first real glimpse into Egyptian monastic economies, with farming, agriculture, and trade. ${ }^{100}$ Important archaeological studies supplement these later texts, analyzing the rubbish in monastic cells to catalog grains and bones. ${ }^{101}$ It is important work, though, as I have noted, little evidence remains from the fourth century.

In his 2016 I pranzi dei santi, Rosenberger wrote that "one could write the history of the monks of Late Antiquity in terms of agon and agency." 102 By agon, Rosenberger was referring to the host of ascetic competitions that monks engaged in, framed in terms of athletics and warfare. ${ }^{103}$ By agency, moreover, Rosenberger was putting forth an argument that such competition was a key source of individuation-that is to say, a monk became an individual and recognizable agent through the praxis he or she elected. ${ }^{104}$ That a monk's praxis (especially vis-à-vis food) was inherently linked to his or her reputation is evident throughout the Sayings, however contradictorily.

Yet this agon was certainly about more than the identity and the reputation of individual monks. It was a question of what monasticism was and what sort of constitution or charter of praxis was most fitting. Thus, I have argued that, in following food through the Sayings, we find ourselves immersed in a politics of communal-identity formation.

\footnotetext{
${ }^{95}$ APalph, Sisoes 2; PG 65:392; and Ward, Sayings, 213.

${ }^{96}$ APalph, Sisoes 8; PG 65:393; and Ward, Sayings, 213-214.

${ }^{97}$ APsys 5.53; and Wortley, Book of the Elders, 86.

${ }^{98}$ APsys 4.98; and Wortley, Book of the Elders, 57.

${ }^{99}$ APalph, Xoios 1; PG 65:312; and Ward, Sayings, 158.

${ }^{100}$ See the thorough analysis in Wipszycka, Moines et communautés, 471-533; or, more briefly, Wipszycka, Second Gift, 457-486.

${ }^{101}$ See Mossakowska-Gaubert, "Alimentation," 25-33; and Brooks Hedstrom, Monastic Landscape, passim.

${ }^{102}$ Rosenberger, I pranzi, 58; and translated in Alciati, “Agon and Agency," 44.

${ }^{103}$ See Paul's promotion of himself as a successful athlete in 1 Cor. 9:24-27. That he held out his life as an exemplum to his disciples is clear (cf. 1 Cor. 11:1).

${ }^{104}$ As discussed in Alciati, "Agon and Agency," 44-50; and see the comments on individuation and diet in Rosenberger, “Divine Diets,” 136.
} 
Brakke has noted that, for Athanasius, the ascetic technologies of self-formation were, indeed, "technologies of power." ${ }^{105}$ More specifically, Athanasius argued that ascetic practice was a constitutive element of the $\pi 0 \lambda \imath \tau \varepsilon i \alpha$ whose source was from heaven but that was instantiated in earthly ecclesial communities under the famed archbishop's sway. ${ }^{106}$ The Sayings betray this selfsame concern with asceticism, identity, and authority. Their treatment of food and eating is no exception.

There are many means for social groups to define themselves. In the Sayings, in particular, it is helpful to focus on performative and public acts of eating or refraining. What does such a focus tell us? It tells us that the earliest layer of Christian monastic literature is already bound up in a dialectic of openness and closedness. And this, I think, is merely a symptom of the competing impulses that ran through the heart of the ancient Christian tradition itself. It is a product of a religion that offers universal grace while at the same time demanding perfection. This contradiction, I would assert, is simply fruit of its own diverse and often irreconcilable scriptures. (Compare, for example, "Be perfect as your Father in Heaven is perfect," and, "The sinners and tax collectors go in before you"!) What is remarkable about the ethos of the Sayings, however, is that late antique monks seemed to resist the temptation to synthesize and reconcile these diverse texts-a temptation that would seduce many a great theologian. ${ }^{107}$ This failure of synthesis is not a weakness-rather, it is the genius of the collection. One elder said, "To be hard on oneself in every respect-that is the way of God." "108 Then again, the Sayings praise another brother who never broke his constant habit of porneia. Rather, it was only "his hope and his shamelessness in the face of God" that saved his soul. $^{109}$

We can see reverberations of these tensions and arguments throughout subsequent monastic literature and the Christian tradition as a whole. Similar strategies and stories appear in the East and the West. A quick survey of the angry correspondence of recrimination between the monasteries of Cluny and Clairvaux in twelfth-century France brings up immediately recognizable tropes: Bernard was aghast at purported intemperance of the Cluniacs in food and drink; ${ }^{110}$ the Cluniacs responded that the Cistercians had, in their love of monastic scruples, neglected both humility and charity. ${ }^{111}$ The tension between these two poles-allowance and asceticism-may also have erupted in the absurd logic of the Byzantine and Russian holy fool, whose own severity or laxity is exercised in intentional parody and farce. ${ }^{112}$ We might even go so far as to speculate that such a tension serves as a helpful (if incomplete) cipher on the theologies of the

\footnotetext{
${ }^{105}$ Brakke, Politics of Asceticism, 143.

${ }^{106}$ Brakke, Politics of Asceticism, 164-165.

${ }^{107}$ On the approach to the scriptures in the early Egyptian monastic literature, see again Burton-Christie, The Word in the Desert.

${ }^{108}$ APsys 21.19; and Wortley, Book of the Elders, 378.

${ }^{109}$ APsys 15.118; and Wortley, Book of the Elders, 277-278.

${ }^{110}$ Bernard, Apologia ad Guillelmum abbatem 8.16.

${ }^{111}$ Peter the Venerable, Epistula 28. For more on this dispute in the context of food culture, see Paul Freedman, Out of the East: Spices and the Medieval Imagination (New Haven: Yale University Press, 2008), 150-153.

${ }^{112}$ See, e.g., Sergey Ivanov, Holy Fools in Byzantium and Beyond (Oxford: Oxford University Press, 2006). Ivanov discusses early monastic literature at 29-48. The holy fool Simeon's outrageous indulgence and abrogation of fasting regulations serves as a prime example in the literary heritage of Byzantine piety. See Derek Kreuger, Symeon the Holy Fool: Leontius's Life and the Late Antique City (Berkeley: University of California Press), 44-47, esp. 46 for Simeon's transgressive eating habits.
} 
Reformers, not least their particular categorizations of "Law" and "Gospel" and subsequent greater emphasis on the letters of Paul over the Jesus of the Gospels. ${ }^{113}$ But speculation aside, the Sayings remain exceedingly interesting, perplexing, and often charming. They provide portraits that later Christians would venerate and seek to imitate. They offer useful details into the practicalities of feeding oneself in the late antique monastic landscape of the Eastern Mediterranean and offer insights into the communal politics of this new city of the desert, a politics very much tied to the table.

Benjamin Hansen is a doctoral candidate in late antique and medieval history at the University of Minnesota, Twin Cities. He is interested in monasticism, early Islam, and the emergence of Christian Arabic. His forthcoming dissertation addresses the social history of Palestinian Christians in the seventh and eighth centuries.

\footnotetext{
${ }^{113}$ See, inter alia, Jaroslav Pelikan, The Christian Tradition: A History of the Development of Doctrine, 4: Reformation of Church and Dogma (1300-1700) (Chicago: The University of Chicago Press, 1984)167-182, 212-215; and R. Ward Holder, "Introduction-Paul in the Sixteenth Century: Invitation and a Challenge," in The Brill Companion to Paul in the Reformation, ed. R. Ward Holder (Leiden: Brill, 2009), 1-12.

Cite this article: Hansen, Benjamin. "Bread in the Desert: The Politics and Practicalities of Food in Early Egyptian Monasticism.” Church History 90, no. 2 (June 2021): 286-303. https://doi.org/10.1017/ S0009640721001499.
} 